\title{
Judicial Review of The Implementation of Corporate Social Rensposibility PT. CG Agriculture Development In Merauke Regency
}

\author{
$1^{\text {st }}$ Yuldiana Zesa Azis \\ Law of Science Department, \\ Faculty of Law \\ Universitas Musamus \\ Merauke, Indonesia \\ shesaazis@yahoo.com
}

\author{
$2^{\text {nd }}$ Erni Dwita Silambi \\ Law of Science Department, \\ Faculty of Law \\ Universitas Musamus \\ Merauke, Indonesia \\ erni@unmus.ac.id
}

\author{
$3^{\text {rd }}$ Marlyn Jane Alputila \\ Law of Science Department, \\ Faculty of Law \\ Universitas Musamus \\ Merauke, Indonesia \\ marlynjane16@gmail.com
}

\begin{abstract}
Merauke Regency is one of the 29 districts in Papua Province which has the widest area of $44,071 \mathrm{~km} 2$. But each region has a different pattern of economic growth from other regions. Each of these economic development efforts has the main objective to increase the number and type of employment opportunities through employment opportunities that are opened by companies that make investments that are beneficial to the Merauke district community. The company as an entity of a legal entity has corporate social responsibility, while the purpose of corporate social responsibility as set forth in Article 1 point 3 of Law Number 40 of 2007 concerning Limited Liability Companies is to improve the quality of life and a beneficial environment. for the Company itself, the local community and society in general. PT CG. Agriculture Development is one of the Foreign Investment / PMA companies headquartered in Merauke Regency. The company is engaged in the cultivation of cassava and processing of tapioca flour industry. The purpose of this study was to find out how corporate social responsibility is implemented by PT CG. Agriculture Development. The results showed that PT CG. Agriculture Development has not fully implemented CSR because in reality there are several companies that have not carried out commercial activities or have not operated in their working area. The implementation of corporate social responsibility is still focused on areas such as social, sports, health and education.
\end{abstract}

Keywords-Merauke regency, investment, company, corporate social responsibility

\section{INTRODUCTION}

Merauke Regency is one of the regencies in the Papua Province where it is geographically located between $137^{\circ}-141^{\circ}$ East Longitude and $5^{\circ}-9^{\circ}$ South Latitude. With an area of up to $46,791.63 \mathrm{~km} 2$ or 14.67 percent of the total area of Papua Province, Merauke Regency is the largest district not only in Papua Province but also among other districts in Indonesia. Administratively, Merauke Regency has 20 districts, where Waan District is the widest district, reaching $5,416.84 \mathrm{~km} 2$, while Semangga District is the smallest district with an area of only $326.95 \mathrm{~km} 2$ or only 0.01 percent of the total area of Merauke Regency. While the area of water in Merauke Regency reaches 5,089.71 km2 [1].

The area of Merauke Regency is $44,071 \mathrm{~km} 2$ (Merauke in number, 2013), which consists of 20 districts with the furthest district is the Muting district, $247 \mathrm{~km}$ from the district capital. Waan District is the widest district, reaching $5,416.84 \mathrm{~km} 2$ or around $11.58 \%$ of the total area followed by the Ulilin District covering $5,092.57 \mathrm{~km} 2$ or $10.88 \%$ [2]

The most prominent economic potential in Merauke Regency is the agriculture and plantation sector because it is supported by the geographical location of the region. In addition to the agricultural sector, the sectors that support the economy of Merauke Regency are the industrial, trade and services sectors. However, with the existence of MopahMerauke Airport as a transportation and communication sector, it becomes a much higher added value compared to the agricultural and plantation sectors and other sectors..

Based on the description above it can be seen that Merauke Regency has the opportunity to open opportunities for entrepreneurs who want to invest. The Merauke Regency Regional Investment Board (BPMD) records that there are 28 companies that invest, but of that number, only a few operate like oil palm plantations or industrial timber plantations (HTI). While others, it does not work at all, including sugarcane plantation permits .

PT CG. Agriculture Development is one of the Foreign Investment / PMA companies headquartered in Merauke Regency. The company is engaged in the cultivation of cassava and processing of tapioca flour industry. The company carries out its business activities based on the Regent's Decree Number 277 of 2010 concerning the Granting of Land Permits for an Area of 20,000 Hectares for Business Needs of Food Crop Cultivation in Okaba District, Merauke Regency. The concession area for the company's business is located in eight villages scattered in the Okaba District. 
The company as a legal entity entity has corporate social responsibility (Coorporate Social Responsibility). In practice, so far there are still several companies that carry out corporate social responsibility programs that are only voluntary in nature that do not have a sustainable commitment. A survey from Kompas Daily about the implementation of corporate social responsibility in 2015 stated that corporate social responsibility activities are only carried out at $\pm 50 \%$ of all companies operating in Indonesia, and their own activities are more focused on philanthropy and charity in order assisting victims of natural disasters.3 Whereas corporate social responsibility activities are an ongoing joint commitment of all company stakeholders to jointly be responsible for social problems[3].

People, enterprises, civil organizations and the government to promote corporate social responsibility movement carried out a series of attempts and practice, and achieved some results. But now also mainly by the enterprise's conscious behavior and moral constraints to maintain. The relevant laws of the state also involve corporate social responsibility, but most of them are principled and indirect, and there is some difficulty in the practical operation level.

This research is useful for analyzing the implementation of CSR in Merauke Regency and finding common solutions to CSR problems for the welfare of the community so that there is no development and economic gap in the area of the company. The limitation in this study is to only discuss the legal review of CSR implementation in PT CG. Agriculture Development.

\section{RESEARCH METHODS}

The method used in this legal research is an empirical juridical legal research method is a research method that serves to be able to see the law in two meaning yankni from the law and examine how the law works in the community. Because of this empirical juridical legal research is to examine people in the relationship of life in society. Because this legal research is taken from the facts that exist in a community, legal entity or government agency and the relevant law. As well as this study uses a qualitative approach, that what you want to get and study by a study qualitative is thinking, meaning, human perspective about the symptoms that become the focus of the research. The meaning of thought and so on is an idea not a symptom.

\section{A. Data Collection}

qualitative is thought, meaning, human perspective on the symptoms that become fok The population in this study is PT. CG Agriculture Development and the community. While the sample in this study is from PT. CG Agriculture Development was represented by one of the parties from the company and a sample of the community was represented by several communities who received corporate social responsibility programs from PT. CG Agriculture
Development in Merauke District. The meaning of thought and so on is an idea not a symptom.

\section{B. Analysis and Evaluation}

To get the desired end result, the data obtained from the results of the interviews and literature review were analyzed qualitatively for further data presented in descriptive form. So that this research not only draws a conclusion but can also provide a solution to the problem at hand.

\section{Types and Data Sources}

Supporting data in scientific research consisting of 2 (two) types of data, namely:

1. Primary data, namely data directly obtained in the technical field with the company, namely PT. CG Agricultural Development, represented by company leaders from the community, is represented by students receiving assistance who live in the company's area.

2. Secondary data, namely data collected by reviewing documents relating to the object of research in the form of books, data from the internet, rules for granting invitations, and from various sides that are still related to the object of research.

\section{Data Collection Techniques}

1. To obtain the primary data needed in this study, data collection is carried out through interviews with the company and the community.

2. To obtain secondary data needed in this study, data collection is done through studies of books, data from the internet, legislation, and other written sources related to the object of research.

\section{RESUlt AND DISCUSSION}

\section{A. Overview}

PT CG. Agriculture Development is one of the Foreign Investment/PMA companies headquartered in Merauke Regency. The company is engaged in the cultivation of cassava and processing of tapioca flour industry. The company carries out its business activities based on the Regent's Decree Number 277 of 2010 concerning the Granting of Land Permits for an Area of 20,000 Hectares for Business Needs of Food Crop Cultivation in Okaba District, Merauke Regency. The concession area for the company's business is located in eight villages scattered in the Okaba District. In the implementation plan of its business activities, the company is not enough to only have a Regent Decree concerning the granting of a Location Permit, but the company must complete the licensing stage that must be fulfilled in accordance with the provisions of the prevailing laws and regulations at the district level. And what is certain is that the activities of the company not only manage and utilize existing natural resources, but also must involve the community around the area as a work partner of the company in accordance with the Regulation of the 
Minister of Agriculture of the Republic of Indonesia Number 29 of 2016 concerning Guidelines for Licensing of Plantation Businesses.

\section{B. Corporate Social Responsibility Implementation of PT. CG Agriculture}

During carrying out Investment activities in Merauke Regency within seven years PT. CG Agriculture Development has carried out various programs and activities as Corporate Social Responsibility. The implementation of corporate social responsibility PT. CG. Agriculture Development in the company environment is carried out by Mr. Kim Young Ho was established on May 2, 2010 in accordance with the Deed of Establishment of the Company. This is a serious effort from the beginning of the establishment of PT. CG Agriculture Development to become a company that participates in advancing the nation by improving the quality of human resources and maintaining the sustainability of Indonesia's natural resources.

The implementation of corporate social responsibility from PT. CG Agriculture Development in the form of programs and activities that carry different missions and focus. The programs and activities include:

\section{1) Awarding Scholarships}

PT. CG Agriculture Development realizing that education is one of the efforts to improve the welfare of the people and the nation in realizing a better future. As a company commitment to help improve the welfare of the community through education and to improve community access to education in the country, since 2010 PT. CG Agriculture Development has consistently played an active role in advancing education through the cultivation and empowerment of outstanding students / students, in various soft skills training to shape disciplined, independent and future-minded Indonesian people and become intellectual, emotional, and spiritual leaders.

Scholarship recipients receive a scholarship fund of Rp. 300,000 - Rp. 500,000; every month for 7 years. The goal is none other so that scholarship recipients can become Indonesian people who are disciplined, independent, and future-minded as potential leaders of the nation.

\section{2) Educational Facility Assistance}

Education is something that is very urgent in human life. In reality, education has been able to bring people towards a more civilized life. Education is also the most important investment for the Nation, especially for developing nations. Development can only be done by humans who are prepared through education.

Therefore, education must be prepared to support development through improving Human Resources (HR). Education in its implementation is directed to an orderly, orderly and directed process with media or art, namely management.

PT. CG Agriculture Development seeks to support and motivate one Private School in Merauke Regency to get the title of the best Islamic Primary School in Merauke. This step is realized by providing educational facilities to the school.

The assistance of educational facilities that are realized in the form of giving donations or assistance to purchase drumband art equipment and assistance in sports equipment. This assistance is expected to be able to complement the school facilities that are owned so that students are more eager to follow positive activities in order to increase the healthy generation held in the city of Merauke.

\section{3) Sports Facility Assistance}

Exercise is a good and beneficial activity for the body. However, to do sports must be supported by adequate facilities and infrastructure, except jogging / running sports that can be done on the street or in a room that is not dangerous. Sports that must be supported by adequate facilities and infrastructure are soccer, volleyball, basketball, futsal etc. In its activities PT. CG Agriculture Development involves itself as a sponsor of one of the futsal teams in Merauke Regency to win in the Futsal Tournament. This step is realized by providing sports facilities to the futsal team.

Support for sports facilities that are realized in the form of donations to buy uniforms, shoes, balls and operational costs of training and during the competition. This assistance is expected to complement the futsal facilities that are owned so that young people are more excited and motivated to participate in futsal competitions held in Merauke Regency and outside the Merauke Regency Area.

\section{4) Health Assistance}

Health is one of the main factors that can affect the fitness and appearance of the body, as well as the most valuable assets that have never been exchanged for anything. Therefore, everyone certainly longs for a healthy and happy life. This can be felt if we have been sick. Health is a necessity for everyone, because everyone wants to be healthy, no one wants to be sick or has health problems.

Sports is also certainly a human effort to achieve health, this is a general goal that every human mind has.

In the implementation of health care assistance programs carried out with activities that are beneficial to society and humanity. Health assistance realized by PT. CG Agriculture Development in the form of contributing care to the community around the area of the company that is seriously ill and needs intensive care for health workers, besides that the company also includes all employees in the Social Security/ BPJS Health Agency program. This assistance is expected to reduce the burden of health care costs for sick employees. 
There is also the implementation of activities within the company which are carried out in the form of providing social security in the form of maternity leave, annual leave, annual prizes, holiday allowances, accident guarantees, life insurance and pension guarantees.

As for knowing how far the implementation of corporate social responsibility from PT. CG Agriculture Development is carried out in accordance with the applicable provisions, then an analysis is carried out based on the regulations stipulated in the applicable legal provisions. In this case the analysis is based on the provisions of Law Number 40 of 2007 concerning Limited Liability Companies and Government Regulation Number 47 of 2012 concerning Social and Environmental Responsibilities of Limited Liability Companies[4][5].

\section{CONCLUSION}

After conducting the research, there are several conclusions that can be obtained, including the following:

1. Implementation of corporate social responsibility PT. CG Agriculture Development in general has been implemented based on the applicable provisions, namely the provisions of Law Number 40 of 2007 concerning Limited Liability Companies as an umbrella regulation for the implementation of corporate social responsibility in Indonesia [5] and Government Regulation Number 47 of 2012 concerning Social and Environmental Responsibilities of Limited Liability Companies as implementing regulations [4]. However, there are still weaknesses and shortcomings in the implementation, namely the absence of community development programs and activities (Comunity Development) in the surrounding areas of the company operating, the absence of programs and activities that aim to reduce the negative impact of the use of the products they produce from the company's operations, and only a small part of the implementation of corporate social responsibility carried out by the company's directors.

2. The implementation of corporate social responsibility PT. CG Agriculture Development as a whole has had a positive influence on the community, both the communities around the company's area and the Merauke Regency community in general. This is manifested in improving the quality of life of the people which covers various fields, including social, sports and education. But the implementation of corporate social responsibility PT. CG Agriculture Development has not given influence to community development (Community Development) especially in the economic field in an effort to improve the welfare of the communities around the company's operating area.

\section{ACKNOWLEDGMENT}

Acknowledgments were conveyed to the Rector of Musamus University and Chairperson of Musamus University Research and Community Service Institution (LPPM UNMUS) who have helped in the process of contract research activities of the Beginning Lecturers (PDP) of the 2018
Budget Year in which funding is charged to the DIPA Directorate General of Research and Development Strengthening, Ministry of Research, Technology and Higher Education DIPA so that the research can be completed. The results of the study can finally be published in this article. In addition, the authors would like to thank all both individuals and groups who contributed to the writing of this article even though they were not writers.

\section{REFERENCES}

[1] Badan Pusat Statistik Kabupaten Merauke, "Kabupaten Merauke dalam Angka 2016," 2017.

[2] Badan Pusat Statistik Kabupaten Merauke, "Merauke Dalam Angka 2014," 2015.

[3] U. Azheri, Corporate Social Responsibility:Dari Voluntary Menjadi Mandatory. Jakarta: Rajawali Pers.

[4] Presiden Republik Indonesia, Peraturan Pemerintah Republik Indonesia Nomor 47 Tahun 2012 Tentang Tanggung Jawab Sosial Dan Lingkungan Perseroan Terbatas. Indonesia, 2012

[5] Presiden Republik Indonesia, Undang-Undang Republik Indonesia Nomor 40 Tahun 2007 Tentang Perseroan Terbatas. Indonesia, 2007 